\title{
Calcium Intake and the Outcome of Short-Term Weight Management
}

\author{
K. KABRNOVÁ - HLAVATÁ ${ }^{1}$, V. HAINER ${ }^{1}$, M. GOJOVÁ ${ }^{2}$, P. HLAVATÝ ${ }^{1}$, V. KOPSKÝ ${ }^{1}$, \\ J. NEDVÍDKOVÁ ${ }^{1}$, M. KUNEŠOVÁ ${ }^{1}$, J. PAŘIZZKOVÁ ${ }^{1}$, M. WAGENKNECHT ${ }^{1}$, M. HILL ${ }^{1}$, \\ J. DRBOHLAV
}

${ }^{1}$ Institute of Endocrinology, Obesity Management Center, Prague, ${ }^{2}$ Obesity Management Unit, Lipová Lázně and ${ }^{3}$ Dairy Research Institute, Prague, Czech Republic

Received July 3, 2006

Accepted March 23, 2007

On-line available May 30, 2007

\begin{abstract}
Summary
Experimental and epidemiological studies suggest that calcium intake is inversely related to weight gain. Calcium of dairy origin has been shown to be more effective in promoting weight loss. However, clinical studies yielded controversial results concerning the role of calcium intake in weight change. The aim of this study was to ascertain whether the addition of calcium can affect the outcome of 3-week weight management (WM) with a hypocaloric diet characterized by a decreased calcium intake. Overweight/ obese women $\left(n=67 ;\right.$ BMI $32.2 \pm 4.1 \mathrm{~kg} / \mathrm{m}^{2}$; age $49.1 \pm 12.1$ years) underwent a 4-week comprehensive WM program. WM included a $7 \mathrm{MJ} /$ day diet resulting in a stable weight during the first week and a $4.5 \mathrm{MJ} /$ day diet with mean daily calcium intake $350 \mathrm{mg}$ during the second to fourth week. Participants were divided into three age- and BMI-matched groups who received placebo or calcium (500 mg/day). Calcium was administered either as carbonate or calcium of dairy origin (Lactoval). There was no significant difference in weight loss in response to WM between the placebo-treated and calcium-treated groups. However, addition of calcium to the diet resulted in a lower hunger score in the Eating Inventory as well as a decrease in plasma resistin levels. Body composition measured by bioimpedance demonstrated that added calcium leads to preservation of fat-free mass. Nevertheless, a greater loss of fatfree mass in the placebo group might be partly due to a greater loss of water.
\end{abstract}

\section{Key words}

Obesity - Calcium intake - Weight change - Fat-free mass • Hunger • Resistin

\section{Corresponding author}

V. Hainer, Institute of Endocrinology, Obesity Management Centre, Národní třída 8, 11694 Prague 1, Czech Republic. E-mail: vhainer@endo.cz

\section{Introduction}

Recent studies demonstrated that body weight loss in response to the weight management is influenced not only by the energy intake and macronutrient composition of the diet but also by intake of other nutritional factors, i. e. calcium and n-3 fatty acids (Zemel et al. 2004, Kunešová et al. 2006. Experimental studies have demonstrated that calcium intake lowers body weight in rats and mice (Bursey et al. 1989, Shi et al. 2001). Several observational studies have shown an inverse relationship between dietary calcium intake or intake of dairy products and body weight (Lin et al. 2000, Davies et al. 2000, Zemel et al. 2000, Barger-Lux et al. 2001, Jacqmain et al. 2003, Zemel et al. 2004). Davies et al. (2000) analyzed four observational, two crosssectional and two longitudinal studies and confirmed a significant negative association between calcium intake and body weight. According to this analysis, differences in calcium intake could explain $3 \%$ of the variance in body weight. CARDIA study revealed a negative relationship between calcium intake or dairy consumption and obesity and insulin resistance syndrome (Pereira et al. 2002). Recently, Liu et al. (2005) reported that the intake of calcium and dairy products may be associated with lower prevalence of the metabolic syndrome in middle-aged and older women. In observational studies on the role of calcium intake the confounding factors, such as dairy protein, should be taken into account. In our recent study in 208 obese individuals (BMI 40.0 \pm 7.7 $\mathrm{kg} / \mathrm{m}^{2}$ ) (Kabrnová et al. 2004) body weight changes over 
a 3- to 6-month weight management (WM) were negatively related to changes in the intake of both dietary calcium $(\mathrm{r}=-0.210, \mathrm{p}=0.003)$ and protein $(\mathrm{r}=-0.289$, $\mathrm{p}<0.001)$.

A few of the intervention studies conducted on the role of calcium intake on body weight and body composition yielded conflicting results (Chan et al. 1995, Thompson et al. 2005, Boon et al. 2005, Rajpathak et al. 2006,). It has also been demonstrated that calcium from dairy products is more effective in reducing body weight than calcium from supplements (Zemel et al. 2000, 2004).

Different mechanisms were proposed to mediate the effects of dietary calcium on body weight changes. Formation of fecal fatty acid complexes to reduce fat absorption may represent an important mechanism through which calcium affects body weight regulation (Jacobsen et al. 2005). Elevation of fecal fat excretion in response to increased calcium intake should be considered especially in individuals with an excessive fat intake. Intracellular $\mathrm{Ca}^{2+}$ is a key regulator of lipid metabolism. Its elevated intracellular concentrations stimulate the expression and activity of lipogenic enzymes and reduce lipolysis with a subsequent increased accumulation of fat in adipocytes (Zemel et al. 2000). Dietary calcium-induced suppression of 1.25-dihydroxyvitamin $\mathrm{D}$ diminishes the entry of $\mathrm{Ca}^{2+}$ into adipocytes and as a consequence also diminishes fat storage in adipocytes (Xue et al. 2001, Zemel 2003). Calcium might affect energy balance by stimulating an expression of uncoupling proteins in adipocytes (UCP2) and skeletal muscles (UCP3) (Yu et al. 2003, Zemel et al. 2000, Zemel 2003). Calcium also affects fat oxidation. Melanson et al. (2003) demonstrated that calcium intake correlated positively with $24-\mathrm{h}$ fat oxidation, during both sleep and moderate physical activity.

Food intake, energy balance and body weight as well as insulin sensitivity are regulated by complex neurohormonal signals (Druce and Bloom 2006). Adherence to the WM program is greatly influenced by psychobehavioral factors, among which the eating behavior plays a crucial role. However, an association between calcium intake and hormonal and psychobehavioral factors has not yet been assessed. The aim of the present study was to evaluate whether a calcium supplement (500 mg/day) would influence a change in body weight and body composition in response to a 3-week WM program with strictly defined and supervised caloric intake. The impact of calcium intake on metabolic, hormonal and psychobehavioral parameters was also evaluated.

\section{Subjects and Methods}

Sixty-seven overweight/obese women (BMI $32.2 \pm 4.1 \mathrm{~kg} / \mathrm{m}^{2}$; age: $49.1 \pm 12.1$ years) participated in a 4 week WM program in the Spa Obesity Unit. Subjects with diabetes, uncompensated thyroid dysfunction and those treated with drugs affecting water balance (diuretics, hormonal contraceptive and replacement therapy etc.) were excluded from the study.

The comprehensive WM included a precisely defined low energy diet, daily physical activity supervised by a physiatrist and cognitive behavioral modification of lifestyle. Energy and nutrient content of meals prepared in the hospital kitchen during the entire period of study was calculated by the PC program „Nutrition“. This software covers almost 3000 food items and evaluates the intake of energy, macronutrients and micronutrients. All subjects were advised to eat all of the meals served in four daily portions in the spa dining room. Mean daily energy intake before initiation of the spa treatment was calculated to be about $7 \mathrm{MJ}$. Therefore, the patients were provided a $7 \mathrm{MJ} /$ day diet during the first week of WM. Only those patients who exhibited a stable weight during the first week entered the trial and received a hypocaloric diet providing $4.5 \mathrm{MJ} /$ day (protein $25.3 \%$, fat $28.7 \%$, carbohydrate $46.0 \%$ ) with a low calcium supply ( $350 \mathrm{mg}$ /day) over the subsequent 3 -week period. This diet yielded a 2.5 MJ deficit in comparison with the pretreatment week.

Participants were divided into three age- and BMI-matched groups who received either a placebo (P group, $\mathrm{n}=21)$ or calcium (500 $\mathrm{mg} /$ day), either as carbonate ( $\mathrm{C}$ group, $\mathrm{n}=25$ ) or calcium of dairy origin Lactoval ( $\mathrm{L}$ group, $\mathrm{n}=21$ ). Lactoval was prepared from milk and contained calcium as phosphate $(70 \%)$, lactate $(10 \%)$ and citrate $(20 \%)$. Tablets were analyzed in the Dairy Research Institute and their calcium content corresponded to the declared values. A dietitian distributed placebo or calcium tablets to the patients in three daily doses. The dietitian also checked that the patients took the tablets immediately after receiving them.

The studied women were predominantly perimenopausal. The number of women in menopause was comparable in the groups.

Anthropometric, biochemical, hormonal and 
psychobehavioral investigations were conducted before and after a 3-week WM. Body weight and body composition were analyzed by a bipedal-bimanual Body Composition Analyzer Tanita BC-418MA (Tanita Inc., Tokyo, Japan). Anthropometric measurements included body weight, height, waist and hip circumference, subscapular, triceps, biceps and suprailiac skinfolds.

Eating behavior was evaluated by the Eating Inventory (Stunkard and Messick 1985) which assesses three behavioral traits: 1) dietary restraint - deliberate control of intake, 2) disinhibition - measure a loss of control over food intake (for example in response to stress, anxiety, depression and alcohol intake), 3) perceived hunger -- awareness of and susceptibility to hunger. Beck Depression Inventory (Beck et al. 1961) was used to evaluate the level of depression.

Blood samples for biochemical and hormonal investigations were taken in the morning after a 12-h overnight fast. Biochemical indexes (blood glucose, glycosylated hemoglobin, uric acid, total cholesterol, HDL-cholesterol, LDL-cholesterol, triglycerides, $\mathrm{C}$ reactive protein) were assessed by standard laboratory procedures. Hormonal levels (TSH, fT3, fT4, insulin, $\mathrm{C}$ peptide, prolactin, growth hormone, total ghrelin, IGF1, cortisol, sex hormone binding globulin /SHBG/, leptin, ghrelin, peptide YY, neuropeptide Y, adiponectin, resistin) were analyzed by radioimmunoassay.

Protocol of the study was reviewed and accepted by the Ethics Committee of the Institute of Endocrinology. All patients were informed about the study design and signed an informed consent form concerning their participation in the study.

\section{Statistical analysis}

Results are expressed as means \pm S.D. Differences in parameters before and after WM as well as differences between the groups were assessed using the Kruskal-Wallis robust analysis of variance (ANOVA) followed by Kruskal-Wallis multiple comparisons. Differences between groups were assessed by the MannWhitney test. Changes were evaluated by Wilcoxon's paired test.

\section{Results}

The baseline data were similar in all three groups for body mass index (C group: $32.39 \pm 4.35 \mathrm{~kg} / \mathrm{m}^{2}$, L group: $32.42 \pm 4.22 \mathrm{~kg} / \mathrm{m}^{2}$, P group: $32.36 \pm 4.86 \mathrm{~kg} / \mathrm{m}^{2}$ ), fat stores (C group: 41.3 $\pm 4.9 \%$; L group: $41.7 \pm 6.4 \%$;
P group: $42.0 \pm 5.7 \%$ ) and plasma leptin levels (C group: $21.7 \pm 8.4 \mathrm{ng} / \mathrm{ml}$; L group: $21.5 \pm 9.3 \mathrm{ng} / \mathrm{ml}$; $\mathrm{P}$ group: $20.3 \pm 9.1 \mathrm{ng} / \mathrm{ml}$ ) which under stable weight conditions reflect body fat stores. An average weight loss of $3.8 \pm 1.6$ $\mathrm{kg}$ was achieved in response to WM. Table 1 summarizes significant changes in anthropometric, psychobehavioral and hormonal parameters in the whole cohort. Decreases in body weight, BMI, body circumferences and skinfolds were demonstrated. In response to WM, the Beck depression score, hunger scores and disinhibition scores decreased, whereas the restraint score increased. Significant decreases in serum leptin and NPY levels were shown. A significant decline in fasting blood glucose and insulin concentrations was demonstrated together with a significant rise in SHBG level, whereas no significant changes in serum adiponectin $(-0.06 \pm 2.69$ $\mathrm{mg} / \mathrm{l})$ and resistin $(-0.18 \pm 0.78 \mu \mathrm{g} / \mathrm{l})$ levels were observed.

No significant differences were observed in any anthropometric, body composition, psychobehavioral, biochemical and hormonal parameters when the three groups differing in the calcium intake were compared both before and after the weight reduction. Only selected data from 52 measured parameters are shown in Table 2.

As shown in Table 3, significant decreases in body weight, BMI and fat mass were observed in both the calcium-treated groups and in the group receiving placebo. No significant differences in the decreases in anthropometric indexes and fat mass were demonstrated between the three groups of patients. On the other hand, a significant decline in FFM was shown in the group treated with placebo $(-1.46 \pm 3.36 \mathrm{~kg}, \mathrm{p}=0.006)$, while both groups provided with additional calcium did not exhibit any significant changes in FFM. Hunger score decreased significantly in both groups treated with calcium (calcium carbonate group: $-1.54 \pm 2.59, \mathrm{p}=0.010$; Lactoval group: $-1.76 \pm 2.98, \mathrm{p}=0.017$ ) whereas a decline of hunger score in the placebo-treated group was not significant $(0.38 \pm 2.56)$.

Figure 1 demonstrates a significant difference in the change of resistin level in response to WM between the placebo-treated group and the joint cohort including both calcium-treated groups. In contrast to the WMinduced increase in resistin levels in the placebo-treated group, a decrease in mean resistin level was demonstrated in the joint calcium-treated group.

\section{Discussion}

The main finding of the present study is that the 
Table 1. Anthropometric, psychobehavioral and hormonal indexes and their changes in response to weight management in the whole cohort.

\begin{tabular}{|c|c|c|c|c|c|c|c|}
\hline & \multicolumn{6}{|c|}{ All subjects } & \multirow{3}{*}{$\begin{array}{c}\text { Significance } \\
\text { p }\end{array}$} \\
\hline & \multicolumn{2}{|c|}{ Before } & \multicolumn{2}{|c|}{ After } & \multicolumn{2}{|c|}{ Difference } & \\
\hline & mean & S.D. & mean & S.D. & mean & S.D. & \\
\hline Weight (kg) & 84.60 & 12.81 & 80.78 & 12.48 & -3.82 & 1.63 & 0.000001 \\
\hline$B M I\left(\mathrm{~kg} / \mathrm{m}^{2}\right)$ & 32.39 & 4.48 & 30.92 & 4.33 & -1.47 & 0.63 & 0.000001 \\
\hline Waist (cm) & 98.83 & 11.92 & 93.64 & 11.43 & -5.19 & 2.28 & 0.000001 \\
\hline Hip (cm) & 115.49 & 9.20 & 112.12 & 8.97 & -3.37 & 1.61 & 0.000001 \\
\hline$W H R$ & 0.86 & 0.07 & 0.83 & 0.07 & -0.02 & 0.02 & 0.000001 \\
\hline Fat $(\mathrm{kg})$ & 35.81 & 9.52 & 32.01 & 8.83 & -3.80 & 2.83 & 0.000001 \\
\hline Fat (\%) & 41.65 & 5.69 & 38.98 & 6.12 & -2.67 & 2.89 & 0.000001 \\
\hline$F F M(k g)$ & 48.79 & 4.68 & 48.48 & 5.32 & -0.31 & 3.18 & 0.035526 \\
\hline Beck & 10.38 & 6.37 & 7.56 & 6.43 & -2.82 & 4.16 & 0.000003 \\
\hline Restraint & 10.03 & 4.54 & 12.94 & 4.57 & 2.91 & 4.30 & 0.000004 \\
\hline Hunger & 4.08 & 3.28 & 2.83 & 2.73 & -1.24 & 2.71 & 0.000641 \\
\hline Disinhibition & 6.61 & 2.97 & 4.86 & 2.70 & -1.74 & 2.55 & 0.000008 \\
\hline Glucose (mmol/l) & 5.13 & 1.56 & 4.83 & 1.24 & -0.29 & 1.70 & 0.05 \\
\hline Insulin (mIU/l) & 8.36 & 4.45 & 7.83 & 4.81 & -0.53 & 5.99 & 0.05 \\
\hline SHBG (nmol/l) & 61.49 & 44.21 & 79.08 & 53.73 & 14.89 & 26.72 & 0.000001 \\
\hline Leptin $(\mu g / l)$ & 21.21 & 8.98 & 15.36 & 7.13 & -5.85 & 6.45 & 0.000001 \\
\hline NPY (pmol/l) & 101.8 & 52.31 & 84.14 & 41.08 & -17.7 & 31.49 & 0.000003 \\
\hline
\end{tabular}

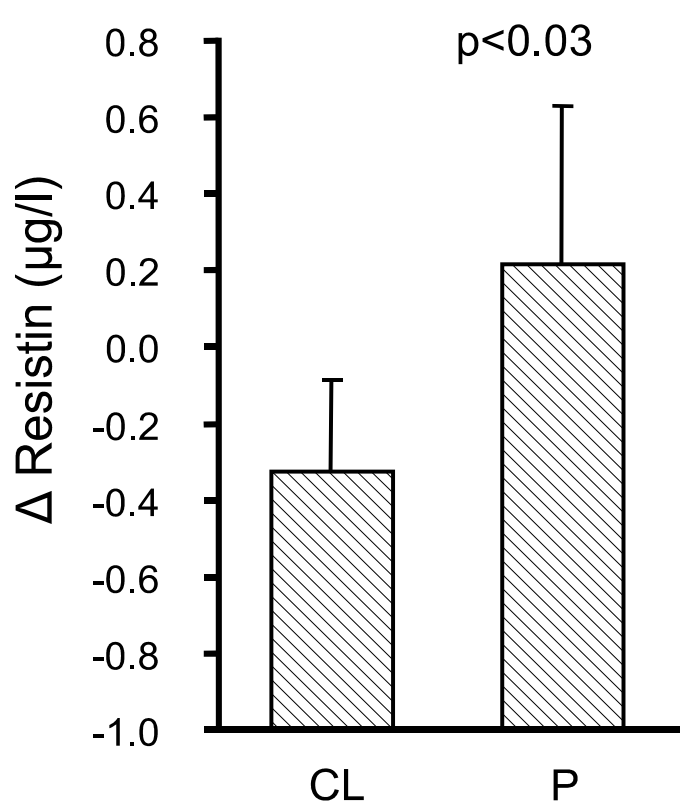

Fig. 1. Change of resistin level in response to $W M$ in the placebo-treated group (group P) and joint calcium-treated group (group $\mathrm{CL}$ ).

administration of a calcium supplement in a daily dose of $500 \mathrm{mg}$ does not result in an increased weight loss during short-term weight management. When discussing the results, we should consider both advantages and limitations of our study. In all previous studies, calcium has been supplemented as calcium carbonate, calcium citrate or calcium citrate-malate, although calcium phosphate represents a major source of calcium in dairy products. No previous studies employed the administration of calcium of dairy origin or calcium phosphate. In our study, patients were given calcium tablets prepared from the milk which also contained calcium as phosphate, lactate and citrate. However, we failed to see any significant difference in body weight loss between the groups supplemented with $500 \mathrm{mg}$ calcium provided as calcium carbonate or as calcium of dairy origin. The second advantage of our study was that we had an opportunity to maintain all subjects on the same diet providing a daily energy deficit of $2.5 \mathrm{MJ}$ with an average daily calculated calcium intake of $350 \mathrm{mg}$. In previously published interventional studies the quantity of calcium obtained from each daily meal had not been evaluated and only the role of supplemented calcium or high dairy product consumption had been considered.

Zemel (2004) reported on weight loss reached over 24 weeks in obese subjects assigned to three different calorie-restricted diets prescribing a daily 
Table 2. Comparison of selected anthropometric, psychobehavioral and hormonal characteristics in placebo-treated group (group P) and in groups treated with calcium carbonate (group C) or with calcium of dairy origin (Lactoval, group L) before and after weight reduction. No significant differences in measured parameters were observed between the groups both before and after weight reduction.

\begin{tabular}{|c|c|c|c|c|c|c|c|c|c|c|c|c|c|c|}
\hline \multirow{4}{*}{ Variable } & \multicolumn{6}{|c|}{ Before } & \multirow{4}{*}{ ANOVA } & \multicolumn{7}{|c|}{ After } \\
\hline & \multirow{2}{*}{\multicolumn{2}{|c|}{$\begin{array}{c}\text { Group } \\
\text { C }\end{array}$}} & \multirow{2}{*}{\multicolumn{2}{|c|}{$\begin{array}{c}\text { Group } \\
\text { L }\end{array}$}} & \multirow{2}{*}{\multicolumn{2}{|c|}{$\begin{array}{c}\text { Group } \\
\text { P }\end{array}$}} & & \multirow{2}{*}{\multicolumn{2}{|c|}{$\begin{array}{c}\text { Group } \\
\text { C }\end{array}$}} & \multirow{2}{*}{\multicolumn{2}{|c|}{$\begin{array}{c}\text { Group } \\
\mathbf{L}\end{array}$}} & \multirow{2}{*}{\multicolumn{2}{|c|}{$\begin{array}{c}\text { Group } \\
\text { P }\end{array}$}} & \multirow{3}{*}{ ANOVA } \\
\hline & & & & & & & & & & & & & & \\
\hline & mean & S.D. & mean & S.D. & mean & S.D. & & mean & S.D. & mean & S.D. & mean & S.D. & \\
\hline Weight (kg) & 84.95 & 11.75 & 83.43 & 11.65 & 85.37 & 14.83 & NS & 81.61 & 11.56 & 79.57 & 11.49 & 81.03 & 14.22 & NS \\
\hline$B M I\left(\mathrm{~kg} / \mathrm{m}^{2}\right)$ & 32.39 & 4.35 & 32.42 & 4.22 & 32.36 & 4.86 & NS & 31.11 & 4.19 & 30.90 & 4.10 & 30.72 & 4.68 & NS \\
\hline Fat (kg) & 35.57 & 9.12 & 35.38 & 9.39 & 36.51 & 10.03 & NS & 31.93 & 7.68 & 31.38 & 9.42 & 32.72 & 9.38 & NS \\
\hline Fat (\%) & 41.30 & 4.98 & 41.70 & 6.39 & 42.01 & 5.69 & NS & 38.69 & 4.54 & 38.71 & 7.58 & 39.58 & 6.03 & NS \\
\hline$F F M(k g)$ & 49.37 & 3.61 & 48.08 & 4.29 & 48.85 & 5.90 & NS & 49.69 & 5.38 & 48.19 & 4.95 & 47.40 & 5.33 & NS \\
\hline Beck & 10.75 & 5.76 & 8.29 & 3.43 & 12.05 & 8.41 & NS & 7.42 & 5.35 & 5.72 & 3.94 & 9.57 & 8.61 & NS \\
\hline Restraint & 10.38 & 3.83 & 9.81 & 4.03 & 9.86 & 5.62 & NS & 13.54 & 4.36 & 12.71 & 3.76 & 12.48 & 5.39 & NS \\
\hline Hunger & 4.54 & 3.04 & 4.24 & 2.99 & 3.38 & 3.68 & NS & 3.00 & 2.84 & 2.47 & 2.06 & 3.00 & 3.13 & NS \\
\hline Disinhibition & 6.79 & 3.04 & 6.95 & 2.90 & 6.05 & 2.90 & NS & 5.42 & 2.96 & 4.81 & 2.95 & 4.29 & 1.88 & NS \\
\hline Leptin $(\mu g / l)$ & 21.74 & 8.47 & 21.47 & 9.31 & 20.34 & 9.14 & NS & 17.51 & 7.67 & 15.13 & 7.51 & 13.13 & 5.01 & NS \\
\hline$N P Y(\mathrm{pmol} / \mathrm{l})$ & 108.30 & 54.23 & 99.07 & 42.45 & 97.17 & 57.96 & NS & 92.09 & 38.87 & 84.26 & 41.20 & 74.92 & 41.51 & NS \\
\hline$A D N(m g / l)$ & 10.66 & 3.09 & 13.07 & 7.35 & 9.99 & 4.22 & NS & 11.09 & 3.70 & 12.35 & 6.27 & 10.39 & 4.02 & NS \\
\hline Resistin $(\mu g / l)$ & 2.68 & 0.89 & 2.33 & 0.65 & 2.15 & 0.65 & NS & 2.08 & 0.54 & 2.28 & 0.80 & 2.37 & 0.99 & NS \\
\hline
\end{tabular}

ADN - adiponectin

Table 3. Changes in selected anthropometric and psychobehavioral characteristics in placebo-treated group (group P) and in groups treated with calcium carbonate (group C) or with calcium of dairy origin (Lactoval, group L). Kruskal-Wallis ANOVA as well as KruskalWallis multiple comparisons found no significant differences in changes between the groups.

\begin{tabular}{lccccccccc}
\hline & \multicolumn{3}{c}{ Group C } & \multicolumn{3}{c}{ Group L } & \multicolumn{3}{c}{ Group P } \\
Variable & Mean & S.D. & P & Mean & S.D. & P & mean & S.D. & p \\
\hline Weight $(\mathrm{kg})$ & -3.34 & 1.79 & 0.00002 & -3.87 & 1.62 & 0.00006 & -4.34 & 1.37 & 0.00006 \\
BMI $\left(\mathrm{kg} / \mathrm{m}^{2}\right)$ & -1.29 & 0.69 & 0.00002 & -1.51 & 0.65 & 0.00006 & -1.64 & 0.49 & 0.00006 \\
Fat $(\mathrm{kg})$ & -3.64 & 3.83 & 0.00002 & -4.00 & 2.73 & 0.00006 & -3.80 & 1.45 & 0.00006 \\
FFM $(\mathrm{kg})$ & 0.32 & 3.49 & 0.64738 & 0.11 & 2.45 & 0.53124 & -1.46 & 3.36 & 0.00630 \\
Restraint & 3.17 & 3.47 & 0.00068 & 2.90 & 4.15 & 0.00767 & 2.62 & 5.44 & 0.05544 \\
Hunger & -1.54 & 2.59 & 0.01013 & -1.76 & 2.98 & 0.01680 & -0.38 & 2.56 & 0.44642 \\
Disinhibition & -1.38 & 2.73 & 0.04447 & -2.14 & 2.61 & 0.00421 & -1.76 & 2.39 & 0.00482 \\
\hline
\end{tabular}

energy deficit of $500 \mathrm{kcal}$ : low dairy, high dairy and calcium-supplemented low dairy. Accelerated weight and fat loss in response to energy restriction was observed in high dairy consumers and calcium-supplemented groups in comparison with low dairy low-calcium consumers (Zemel 2004). It could be objected that our study was conducted over a short period of time and that the amount of supplemented calcium was not high enough to affect the weight loss. The duration of our intervention, only three weeks, was rather short. We were unable to extend the duration of the supervised in-patient stay above the usual 4-wk period of the spa treatment. The lack of evidence for the role of calcium in promoting weight loss in our study might be due to a rather high daily energy deficit which could surpass the effects of calcium over a short-time period of WM. In many interventional studies, patients received $\geq 1000 \mathrm{mg}$ calcium/day. Our calciumsupplemented patients received a total daily dose of 850 
mg calcium on the average which was shown to be sufficient for potentiating weight reduction as well as for its beneficial effects on body composition. According to Thompson et al. (2005) diets higher than $800 \mathrm{mg}$ of calcium in dairy products or higher in fiber and lower in glycemic index do not enhance weight reduction beyond what is seen with caloric restriction alone. The Amsterdam Growth and Health Longitudinal Study which followed a cohort of men and women from age 13 years in 1977 to age 36 years in 2000 suggested a threshold of approximately $800 \mathrm{mg}$ /day above which calcium intake has no additional beneficial effect on body composition (Boon et al. 2005). Barr (2003) in a Medline research project between 1966-2001 identified 17 randomized trials of calcium supplementation in subjects without caloric restriction. In most studies, no differences in body weight or body composition were detected between the calcium and placebo-treated or untreated groups. Recker et al. (1996) in a 4-year study detected a significant difference in body weight change. Postmenopausal women receiving $1.2 \mathrm{~g}$ calcium/day lost $0.35 \mathrm{~kg} /$ year more than did the control group.

Body composition in this study was evaluated by the bioimpedance method which is greatly influenced by the hydration of the examined subjects. Therefore patients treated with drugs which could affect the water balance were not included in the study. Some studies raised questions about the use of bioelectrical impedance (BIA) for evaluation of body composition in obese subjects as well as its changes in response to the weight management (Kyle et al. 2004). However, Jebb et al. (2007) declares that BIA is a useful method for measuring body composition changes during clinical weight management programs. BIA was also classified as a useful tool for body composition assessment in extremely obese subjects before and after massive weight loss induced by gastric bypass surgery (Das et al. 2003). In our study, a significant decrease in fat-free mass (FFM) was demonstrated in the placebo-treated group, whereas loss of FFM was not significant in both calciumtreated groups. It cannot be excluded that the higher loss of body weight in the placebo group $(-4.34 \mathrm{~kg})$ compared to $-3.58 \mathrm{~kg}$ in both calcium-treated groups was partly due to differences in water balance. However, there are no data available about the association of low calcium intake with the loss of water.

On the other hand, the protective effect of calcium intake on FFM was reported by Heaney et al. (2002) in a 3-year calcium intervention trial in young women given either $1500 \mathrm{mg}$ calcium per day or a placebo. The group as a whole had gained weight in a 3-year follow-up; there was no significant difference in weight gain between the calcium-supplemented and control groups. However, the weight gain in the calcium supplemented women consisted primarily in an increase in fat-free mass, while the placebo-treated women accumulated twice as much body fat. High dairy calcium diets in three weight loss studies conducted by Zemel et al. (2004, 2005a, 2005b) induced not only higher fat loss but also markedly reduced the loss of FFM compared with the low dairy calcium diet. Preservation of FFM by dairy products could be attributed to the high content of branched chain amino acids in proteins of dairy origin. Branched chain amino acids, especially leucine, play a key role the regulation of muscle protein synthesis (Layman and Walker 2006). It is difficult to find an explanation how dietary calcium per se might influence preservation of FFM during the weight loss studies. Calcium-induced suppression of 1,25-dihydroxyvitamin $\mathrm{D}$ levels has been proposed as a mechanism leading to reduction of visceral adiposity as 1,25-dihydroxyvitamin $\mathrm{D}$ has been shown to stimulate $11 \beta$-hydroxysteroid dehydrogenase-1 (Morris and Zemel 2005). However, it seems unlikely that such a calcium-induced inhibition of local cortisol production in adipose tissue could play any role in the modulation of overall body protein catabolism.

In addition, a significant decline in the hunger score of the Eating Inventory was demonstrated in calcium-treated groups, but not in the placebo-treated group. This change in perception of hunger could contribute to a better long-term outcome of weight management in calcium-treated patients. However, change in the hunger score does not necessarily implicate change in energy intake which was the same for all participants in our study. The observed decline in the hunger score cannot be attributed to changes in fasting concentrations of hormones involved in food intake regulation. No significant differences in profile of these hormones were seen between the calcium- and placebotreated individuals. However, we did not examine postprandial hormonal responses which could affect both satiety and hunger feelings. Ping-Delfos et al. (2004) reported that a high dairy calcium and vitamin $\mathrm{D}$ diet did not affect subjective sensations of hunger and satiety in the immediate postprandial period, but spontaneous food intake over the subsequent $24 \mathrm{~h}$ period was significantly reduced.

Previous studies demonstrated that a diet 
characterized by a higher calcium intake or higher dairy intake, especially low-fat dairy intake, may lower the risk of type 2 diabetes (Choi et al. 2005, Pittas et al. 2006). A combined daily intake of more than $1200 \mathrm{mg}$ calcium and 800 IU vitamin D was associated with a $33 \%$ lower risk of type 2 diabetes with RR of 0.67 (0.49-0.90) compared with an intake of less than $600 \mathrm{mg}$ calcium and $400 \mathrm{IU}$ vitamin D (Pittas et al. 2006). Among the mechanisms involved in lowering the risk of type 2 diabetes, hormonal mechanisms affecting insulin sensitivity should be considered (Silha et al. 2003, Heilbronn et al. 2004, Lu et al. 2006). A significant difference in the change of resistin levels in response to a negative energy balance was shown in our study between calcium-treated and placebo-treated individuals. Calcium mediated differences in resistin response to weight management might play a role in reducing the risk of type 2 diabetes and metabolic syndrome.

\section{Conflict of Interest}

There is no conflict of interest.

\section{Acknowledgements}

Supported by grants IGA NR/7800-4 and S-QF 3166.

\section{References}

BARGER-LUX MJ, DAVIES KM, HEANEY RP, CHIN BK, RAFFERTY K: Calcium supplementation may attenuate accumulation of fat in young women. J Bone Miner Res 16: 219S, 2001.

BARR SI: Increased dairy product or calcium intake: is body weight or composition affected in humans? $J$ Nutr 133: 245-248, 2003.

BECK AT, WARD CH, MENDELSON M, MOCK J, ERBAUGH J: An inventory for measuring depression. Arch Gen Psychiatr 4: 561-571, 1961.

BOON N, KOPPES LL, SARIS WH, VAN MECHELEN W: The relation between calcium intake and body composition in a Dutch population: The Amsterdam Growth and Health Longitudinal Study. Am J Epidemiol 162: 27-32, 2005.

BURSEY RG, SHARKEY T, MILLER GD: High calcium intake lowers weight in lean and fatty Zucker rats. $F A S E B J$ 3137: 265, 1989.

CHAN GM, HOFFMEN K, MCMURRY M: Effects of dairy products on bone and body composition in pubertal girls. J Pediatr 126: 551-556, 1995.

CHOI HK, WILLETT WC, STAMPFER MJ, RIMM E, HU FB: Dairy consumption and risk of type 2 diabetes mellitus in man: a prospective study. Arch Intern Med 165: 997-1003, 2005.

DAS SK, ROBERTS SB, KEHAYIAS JJ, WANG J, HSU LK, SHIKORA SA, SALTZMAN E, MCCRORY MA: Body composition assessment in extreme obesity and after massive weight loss induced by gastric bypass surgery. Am J Physiol 284: E1080-E1088, 2003.

DAVIES KM, HEANEY RP, RECKER RR, LAPPE JM, BURGER-LUX MJ, RAFFERTY K, HINDERS S: Calcium intake and body weight. J Clin Endocrinol Metab 85: 4635-4638, 2000.

DRUCE M, BLOOM SR: The regulation of appetite. Arch Dis Child 91: 183-187, 2006.

HEANEY RP, DAVIES KM, BARGER-LUX MJ: Calcium and weight: clinical studies. J Am Coll Nutr 21: 152-155, 2002.

HEILBRONN LK, ROOD J, JANDEROVA L, ALBU JB, KELLEY DE, RAVUSSIN E, SMITH SR: Relationship between serum resistin concentrations and insulin resistance in nonobese, obese, and obese diabetic subjects. J Clin Endocrinol Metab 89: 1844-1888, 2004.

JACOBSEN R, LORENZEN JK, TOUBRO S, KROG-MIKKELSEN I, ASTRUP A: Effect of short-term high dietary calcium intake on 24-h energy expenditure, fat oxidation, and fecal fat excretion. Int J Obes 29: 292-301, 2005.

JACQMAIN M, DOUCET E, DESPRES JP, BOUCHARD C, TREMBLAY A: Calcium intake, body composition, and lipoprotein-lipid concentrations in adults. Am J Clin Nutr 77: 1448-1452, 2003.

JEBB SA, SIERVO M, MURGATROYD PR, EVANS S, FRUHBECK G, PRENTICE AM. Validity of the leg-to-leg bioimpedance to estimate changes in body fat during weight loss and regain in overweight women: a comparison with multi-compartment models. Int J Obes 31: 756-762, 2007. 
KABRNOVÁ K, BRAUNEROVÁ R, ALDHOON B, HLAVATÝ P, WAGENKNECHT M, KUNEŠOVÁ M, PAŘÍZKOVÁ J, HAINER V: Association of changes in macronutrient and calcium intakes with body weight change in obese subjects. Int J Obes 28 (Suppl 1): S138, 2004.

KUNEŠOVÁ M, BRAUNEROVÁ R, HLAVATÝ P, TVRZICKÁ E, STAŇKOVÁ B, ŠKRHA J, HILGERTOVÁ J, HILL M, KOPECKÝ J, WAGENKNECHT M, HAINER V, MATOULEK M, PAŘÍZKOVÁ J, ŽÁK A, SVAČINA S: The influence of $\mathrm{n}-3$ polyunsaturated fatty acids and very low calorie diet during a short-term weight reducing regimen on weight loss and serum fatty acid composition in severely obese women. Physiol Res 55: 63-72, 2006.

KYLE UG, BOSAEUS I, DE LORENZO AD, DEURENBERG P, ELIA M, MANUEL GOMEZ J, HEITMANN LB, KENT-SMITH L, MECHIOR JC, PIRLICH M, SCHARFETTER H, SCHOLS A, PICHARD C; ESPEN: Bioelectrical impedance analysis-part II: utilization in clinical practice. Clin Nutr 23: 1430-1453, 2004.

LAYMAN DK, WALKER DA: Potential importance of leucine in treatment of obesity and the metabolic syndrome. J Nutr 136 (Suppl 1): 319-323, 2006.

LIN YC, LYLE RM, MCCABE LD, MCCABE GP, WEAVER CM, TEEGARDEN D: Dairy calcium is related to changes in body composition during a two-year exercise intervention in young women. $J$ Am Coll Nutr 19: 754-760, 2000.

LIU S, SONG Y, FORD ES, MANSON JE, BURING JE, RIDKER PM: Dietary calcium, vitamin D, and the prevalence of metabolic syndrome in middle-aged and older U.S. women. Diabetes Care 28: 2926-2932, 2005.

LU HL, WANG HW, WEN Y, ZHANG MX, LIN HH: Roles of adipocyte derived hormone adiponectin and resistin in insulin resistance of type 2 diabetes. World J Gastroenterol 12: 1747-1751, 2006.

MELANSON EL, SHARP TA, SCHNEIDER J, DONAHOO WT, GRUNWALD GK, HILL JO: Relation between calcium intake and fat oxidation in adult humans. Int J Obes Relat Metab Disord 27: 196-203, 2003.

MORRIS KL, ZEMEL MB: 1,25-dihydroxyvitamin D3 modulation of adipocyte glucocorticoid function. Obes Res 13: 670-677, 2005.

PEREIRA MA, JACOBS DR, VAN HORN L, SLATTERY ML, KARTASHOV AI, LUDWIG DS: Dairy consumption, obesity, and the insulin resistance syndrome in young adults. The CARDIA Study. $J$ Am Med Assoc 287: 20812089, 2002.

PING-DELFOS WC, SOARES MJ, CUMMINGS NK: Acute suppression of spontaneous food intake following dairy calcium and vitamin D. Asia Pac J Clin Nutr 13 (Suppl): 82, 2004.

PITTAS AG, DAWSON-HUGHES B, LI T, VAN DAM RM, WILLET WC, MANSON JE, HU FB: Vitamin D and calcium intake in relation to type 2 diabetes in women. Diabetes Care 29: 650-656, 2006.

RAJPATHAK SN, RIMM EB, ROSNER B, WILLET WC, HU FB: Calcium and dairy intakes in relation to long-term weight gain in US men. Am J Clin Nutr 83: 559-566, 2006.

RECKER RR, HINDERS S, DAVIES KM, HEANEY RP, STEGMAN MR, LAPPE JM, KIMMEL DB: Correcting calcium nutritional deficiency prevents spine fractures in elderly women. $J$ Bone Miner Res 11: 1961-1966, 1996.

SHI H, DIRIENZO D, ZEMEL MB: Effects of dietary calcium on adipocyte lipid metabolism and body weight regulation in energy-restricted aP2-agouti transgenic mice. FASEB J 15: 291-293, 2001.

SILHA JV, KRSEK M, SKRHA JV, SUCHARDA P, NYOMBA BL, MURPHY LJ: Plasma resistin, adiponectin and leptin levels in lean and obese subjects: correlations with insulin resistance. Eur J Endocrinol 149: 331-335, 2003.

STUNKARD AJ, MESSICK S: The three-factor eating questionnaire to measure dietary restraint, disinhibition and hunger. $J$ Psychosom Res 29: 71-83, 1985.

THOMPSON WG, ROSTAD HOLDMAN N, JANZOW DJ, SLEZAK JM, MORRIS KL, ZEMEL MB: Effect of energy-reduced diets high in dairy products and fiber on weight loss in obese adults. Obes Res 13: 1344-1353, 2005.

XUE B, GREENBERG AG, KRAEMER FB, ZEMEL MB: Mechanism of intracellular calcium inhibition of lipolysis in human adipocytes. FASEB $J$ 17: 2527-2529, 2001.

YU X, SUN C, LIU R, LI Y: The effect of dietary calcium on the expression of uncoupling protein 3 gene in skeletal muscle of rat fed with high fat diet. Wei Sheng Yan Jiu 32: 204-207, 2003. 
ZEMEL MB: Calcium modulation of adiposity. Obes Res 11: 375-376, 2003.

ZEMEL MB: Role of calcium and dairy products in energy partitioning and weight management. Am J Clin Nutr 79: 907-912, 2004.

ZEMEL MB, SHI H, GREER B, DIRIENZO D, ZEMEL PC: Regulation of adiposity by dietary calcium. FASEB $J$ 14: 1132-1138, 2000.

ZEMEL MB, THOMPSON W, MILSTEAD A, MORRIS K, CAMPBELL P: Calcium and dairy acceleration of weight and fat loss during energy restriction in obese adults. Obes Res 12: 582-590, 2004.

ZEMEL MB, RICHARDS J, MATHIS S, MILSTEAD A, GEBHARDT L, SILVA E: Dairy augmentation of total and central fat loss in obese subjects. Int J Obes 29: 391-397, 2005a.

ZEMEL MB, RICHARDS J, MILSTEAD A, CAMPBELL P: Effects of calcium and dairy on body composition and weight loss in African-American adults. Obes Res 13: 1218-1225, $2005 \mathrm{~b}$. 